\title{
When the chalks are down: the political economy of teachers' unions protest actions under Ghana's Fourth Republic
}

\section{Quando a aula termina: a política econômica das manifestações dos sindicatos de professores na Quarta República de Gana ${ }^{1}$ \\ Cuando la clase termina: la política económica de las manifestaciones de los sindicatos de profesores en la Cuarta República de Gana \\ AKWASI KWARTENG AMOAKO-GYAMPAH}

\begin{abstract}
This article examines teachers' unions protest actions under Ghana's Fourth Republic. Situating the analysis within Ghana's evolving political economy, I show how constraints in Ghana's political economy as well as its often-faltering macro-economy have influenced and shaped teachers protest actions as well as conditioned governments' responses to teachers' unions' demands.
\end{abstract}

Keywords: teachers' protest actions; economy; Ghana's Fourth Republic.

Resumo: O presente artigo examina os protestos dos sindicatos de professores sob a Quarta República de Gana. Situando a análise dentro da evolução de sua economia política, eu mostro como as restrições na política econômica de Gana, bem como sua macroeconomia muitas vezes instável, influenciaram e moldaram os atos de protestos, assim como condicionou as respostas dos governos às demandas dos sindicatos dos professores.

Palavras-chave: manifestações de professores; economia; Quarta República de Gana.

Resumen: El presente artículo examina las protestas de los sindicatos de profesores bajo la Cuarta República de Ghana. Situando el análisis dentro de la evolución de su economía política, muestra cómo las restricciones en la política económica de Gana, así como su macroeconomía muchas veces inestable, influenciaron y moldearon los actos de protestas, así como condicionaron las respuestas de los gobiernos a las demandas de los sindicatos de los profesores.

Palabras clave: manifestaciones de profesores; economía; Cuarta República de Gana. 


\section{INTRODUCTION}

Teaching has been a significant profession and continues to play a crucial role in every part of the world. It has been a critical avenue for social mobility and employment for the working class and sometimes middle-class people (Robertson 2000). Teaching has often taken place within a political and economic context where education was considered as a public good and the responsibility of the state until in recent times, when under the sway of neo-liberal orthodoxies, most governments have cut their educational budgets considerably (Compton \& Weiner 2008). Yet, most states strive to maintain a firm grip on the education sector due to its potential as a tool for social control and national development. Teachers, being key stakeholders in the education area, also seek to advance their interest and facilitate their social mobility through the education system. The contribution of teachers towards producing skilled personnel needed for national development is acknowledged worldwide. Yet most countries, particularly those in the global south, are reluctant to resolve the myriad of challenges facing teachers and the teaching profession (see Sang 2002). Teachers have thus sought to work through their unions to limit the effects of state regulations that limit their pay, job security and to shape their conditions in ways that they consider as appropriate. Teacher unionism has thus become a tool for teachers to assert themselves in the education sector.

As elsewhere in the world, Ghanaian teachers are core not only to the educational apparatus but also to the political machinery. Their role as professionals who inculcate societal norms and values into the future generation of young leaders makes them indispensable to the state. The Ghanaian state regards its teachers as agents for social control and national development. However, in recent times, developments in the teaching field point to the fact that, while the Ghanaian state expects its teachers to work assiduously as its agents, it hardly rewards them adequately in terms of remuneration (see Osei 2006; AmoakoGyampah 2015). Even though teachers' remuneration has improved significantly since the 2000s, most teachers continue to complain about the inadequacy of their monthly earnings (Amoako-Gyampah, 2015). Beyond poor remuneration, some teachers in Ghana work under stressful conditions. They teach in over-crowded classes, teach children under trees, and work in communities that lack access to basic social amenities. Even under these difficult conditions, Ghanaian teachers are expected to ensure a hundred percent pass rate. They are often accused by individuals, parents, communities, and the government of failing the education system. Yet, from the point of view of teachers, governments over the years have not done enough to improve their conditions of service. 
Subsequently, the prestige that was accorded to teachers in the past is fast diminishing as teachers are ranked in the "public eye" as amongst the least paid professionals in the country. Teachers in Ghana have organized through their unions to protest their deteriorating work conditions and to demand fair remuneration and improved conditions of service. The state, however, seldom accede to these demands. Consequently, strikes and protest actions appear to have become an annual ritual in the education sector since 1992. This paper is a historian's attempt to contextualize organized teachers' protest actions, grounding the analysis in Ghana's political economy. I do not pretend to give a detailed description of these protest actions. Instead, I highlight in what ways these protests have manifested, what factors have shaped and conditioned these protests actions and how those in power have responded. I will limit my analysis to the period of the National Democratic Congress (NDC) and New Patriotic Party (NPP) administrations spanning 1992/3 to 2008. This allows for an examination of teachers protest actions under the two different governments (National Democratic Congress, 1992/93-2000 and the New Patriotic Party, 20012008) that have reigned since the inauguration of the Fourth Republic - thus sensitizing us to similar and different conditions under the two governments that has precipitated teachers' protestations as well as the similarity or otherwise of responses by these governments to the teachers protests. The paper is structured into six sections. The introduction is followed by the context and provenance of teacher unionism in Ghana. The next section provides a snapshot of labor and Ghana's evolving political economy. Section four gives an account of teachers protest actions under the NDC regime and section five brings an account of protest actions under the NPP administration. Section six is a conclusion that ties up the strands of arguments from all the sections.

\section{THE CONTEXT AND PROVENANCE OF TEACHER UNIONISM IN GHANA}

Some account of the development of teacher unionism in Ghana is necessary by way of preliminary. Currently, there are two major teacher unions representing teachers at the pre-tertiary level in Ghana. ${ }^{2}$ These are the Ghana National Association of Teachers (GNAT) and the National Association of Graduate Teachers (NAGRAT). GNAT is the older and the larger amongst the teachers' unions. Teachers were among the earliest groups of workers in Ghana

\footnotetext{
2

Recently, a third teachers' organisation, the Coalition of Concerned Teachers Association - Ghana (CCTA $-\mathrm{GH}$ ) has been formed. We wait to see if this association will survive to be the third labour force in the education sector.
} 
to form associations. Indeed, the formation of teachers' associations could be traced to the 1920s. The earliest teachers' association was formed among government school teachers around 1926. It was called the Government School Teachers Association (GSTA) (see Amoako 2014a; 2014b; 2014c; Darkwah 2014). It is believed that the formation of this association was sponsored by the then colonial Director of Education, J. D. Oman (Amoako 2014a). The aim of the GSTA was to be non-sectarian and non-political and to concentrate on improving classroom teaching and related professional issues (Darkwah 2014, 6). The question of demanding for improved salaries and related conditions of service could not have arisen because, their sponsor, the director of education being a government representative - could not have organized teachers to make demands on the government for improved conditions of service and increased wages for teachers. The GSTA remained dormant throughout the 1930s and was revived and renamed the National Union of Teachers (NUT) in the 1940s. As Darkwah (2014) has suggested, from the point of view of modern activism, this first teachers' association could not have been a good pedigree for subsequent teachers' unions.

The first teachers' association in Ghana that organized on trade union principles emerged in the early 1930s. It was named the Assisted School Teachers Union (ASTU) because it represented the interest of teachers who worked in assisted schools - that is schools managed by Christian missions with assistance in the form of grants-in-aid from the colonial government (see Amoako 2014a; 2014b; 2014c). The ASTU was formed in 1932 and was officially inaugurated in 1933 (see Amoako 2014a). Its formation was prompted by a cut in government's expenditure on education. The cut affected mission school teachers the most as the grant given to their missions was reduced by 25 percent. Subsequently, most mission school teachers were retrenched and those who were retained had their salaries reduced considerably (see Amoako 2014a; Darkwah 2014). The ASTU thus emerged to protest and reverse the adverse effects of the government's budget cut on mission school teachers. They adopted what may be described as trade union strategies such as protests, petitions, deputations and lobbying of the African members of the Legislative assembly, to fight against the reductions (Darkwah 2014; Amoako 2014a). Eventually, the ASTU succeeded in persuading the government to withdraw the proposed cut (Amoako 2012, p. 50). In 1937 the ASTU was renamed the Gold Coast Teachers' Union of (GCTU) - this name change was necessary to shun it of its sectarian character and to open its doors to teachers of all shades.

By the 1950s, several teacher organizations had been formed in addition to the GCTU and the NUT. Most of these associations were formed 
based on church denomination affiliations, subject areas, levels of educational qualification, and the level of the educational system at which the teachers taught (Amoako 2014a; 2014b; 2014c). For example, there were the Catholic, Methodist, Presbyterian schools' teachers' unions; the African Graduate Teachers Association; the Mathematics Teachers Association; and the Training College Teachers' Association (Asiedu-Akrofi 1971, p. 25; Amoako 2014a). Attempts at unifying these unions into a common teachers' organization were frustrated by a misunderstanding between the NUT and the GCTU. Their disagreement revolved around the question of organizational strategy and struggle over leadership positions - the GCTU favored a teachers' association that operated as a professional union whereas the NUT advocated for a teachers' organization that operated on trade union principles (Amoako 2014a; 2014b; 2014c). Beyond the disagreement over organisational strategy, both the GCTU and NUT claimed that they were more representative of teachers in the country and deserved to assume leadership role if they united into a single union. ${ }^{3}$ It took government intervention and the promulgation of the Industrial Relations Act, 1958, to compel all teacher organisations to join other workers in the education sector to form a single union - which was named the Union of Teachers and Education Institution Workers (UTEIW). This union was inaugurated in December 1958 and was affiliated to the umbrella trade union organisation, the Ghana Trade Union Congress (GTUC) (Amoako 2014a, pp. 68-69). In 1960 the UTEIW changed its name to the Union of Teachers and Cultural Services (UTCS) and in 1962 broke off from the GTUC and formed the Ghana National Association of Teachers. ${ }^{4}$

GNAT remained the only union for teachers at the pre-tertiary level until the emergence of a new union - the National Association of Graduate Teachers (NAGRAT) - in the early 1990s. NAGRAT began as a pressure group within GNAT until 1998 when it finally broke off and became the second union for teachers in the education sector representing mainly the interest of graduate teachers within the Ghana education service (Amoako 2014b; Amoako-Gyampah 2015). The reasons for the formation of the NAGRAT are varied and contested (see Darkwah 2014). However, the central concern that ignited the formation of the union seemed to have been the perceptions that the GNAT leadership was indifferent to the concerns of its graduate members (Amoako 2014c). For example, the graduate teachers could not understand why the GNAT was reluctant to lead the demands for graduate teachers to be put on a separate salary scale

3 For details see Amoako (2014a); Darkwah (2014)

4 The reasons for the break away from GTUC have been detailed by Amoako (2014a), 69-70 
which had been recommended by the Gyampo Salary Revision Commission ${ }^{5}$ (see Darkwah 2014). Whatever the reasons that caused the graduate teachers to break off from GNAT; NAGRAT has become one of the key actors in the education labour terrain. Having provided this brief account of teacher unionism in Ghana, it is imperative that we look at labour and Ghana's evolving political economy. This will provide a broad context for our subsequent discussion of teachers' grievances and protest actions. The next section therefore provides a snapshot of Labour and Ghana's political economy from the 1950s.

\section{LABOUR AND GHANA'S EVOLVING POLITICAL ECONOMY}

Since independence in 1957, Ghana has witnessed nine changes in government, including four military coups. The last coup brought into power Jerry John Rawlings who remained in office as a military dictator until 7 January 1993 when the fourth republic was inaugurated and continued thereafter as a constitutionally elected President until 2000 when his party, the National Democratic Congress (NDC) lost power to the opposition New Patriotic Party (NPP) which was led by John Agyekum Kufour. For most part of Ghana's post-colonial political history, to borrow the words of Jeon (1998) "Economic mismanagement has been the most common source of dissatisfaction. Problems with distribution of resources among interest groups, along with economic stagnation, often created conditions for political protest" (p. 218). Organised labour has in most instances been very active in such political protests. Adu-Amankwah and Tutu (1997, p. 207) have observed that government's economic policies spanning the period after independence have had different implications for labour and have contributed to shaping labour relations as well as government-trade union relationship.

Indeed, political discontent following poor economic performance of the Nkrumah ${ }^{6}$ led Convention People's Party (CPP) government led to the first coup in the country in 1966. Even though, the trade union movement was closely allied to the CPP government, there were often sporadic workers strikes in response to the CPP government's dismal economic performance, some of which became national in outlook involving most public sector workers (see Jefferies 1978; Kraus 1979). There is no doubt that workers agitation added to the unpopularity of Nkrumah's government and its eventual overthrow. Similarly, popular opposition

5 The government of Ghana having identified problems with the public sector pay structure constituted the Gyampo Salary Review Commission to study the placement and salary structure of the sector. The commission recommended that graduate professional and graduate non-professional teachers should be put on a separate hierarchical structure for salary purposes (Daily Graphic Report of the Gyampo Salary Review Commission, 11 May 1994, 6.)

6

Kwame Nkrumah was the first President of Ghana. 
to devaluation amidst economic decline led by workers partly triggered the coup that overthrew Busia's government in 1972 (Kraus 2008; Jefferies 1982). The National Redemption Council (NRC) and the Supreme Military Council (SMC I\&II), the regime that was established following Busia's overthrow was kicked out of power because of poor economic performance and high levels of official corruption. The coup that brought Rawlings to power was staged on the heels of political chaos brought about partly by convulsive workers' strikes following the failure of the Limann-led People's National Party (PNP) government to arrest Ghana's economic decline (see Jeon 1998, p. 220).

Ghana's dismal economic performance and unstable growth since independence coupled with persistent economic decline in the 1970s and the inability of the Rawlings-led regime to resolve Ghana's economic problems with a home-grown policy led to the adoption of the International Monetary Fund (IMF) and the World Bank's tailored structural adjustment policies in the early 1980s. With the implementation of the adjustment policies, albeit austere, Ghana began to experience moderate and sustained economic growth after 1985, experiencing higher growth rates in the 2000s (Lindsay 2011; Aryeetey \& Kanbur 2008). In spite of this modest growth, the country could not progress very much. Ghana continued to rely on its traditional export commodities - gold and cocoa (see Aryeetey \& Kanbur 2008; Bob-Milliar \& Bob-Milliar, 2010). Indeed, at the beginning of the 1990s, cocoa contributed 50 to 60 percent of export revenue, about 20 percent of government revenue and about 7 percent to GNP. This trend would continue into the 2000s as growth during the first half of the 2000s was largely driven by performance of gold and cocoa exports - indeed Ghana benefited from the civil war in Cote d'Ivoire and the consequent increase in the world price of cocoa (Lindsay 2011a, p. 7; Lindsay 2011b, p. 13). Again, the huge inflow of foreign aid as a major source of investment during the period of adjustment made Ghana's growth efforts unsustainable as a reduction in aid inflow in the 1990s jeopardized Ghana's economy (Killick 2000).

Ghana's macro-economy in the 1990s was marked with instability. This was due largely to government's profligate spending, and fluctuations in international commodity prices. The problem worsened as the IMF suspended its concessional credit flows under its lending agreement with the country as punishment for the NDC government's loss of fiscal discipline (Lindsay 2011b). Apart from having to service debts accruing from inefficiently managed stateowned enterprises, the government was hardly able to generate anticipated revenue due to policy reversals. Beyond this the government engaged in 'politically motivated' expenditure in the run-off to the 1992 and 1996 elections - providing unbudgeted for rural infrastructure and increasing public sector wages to win 
rural and urban votes respectively (Lindsay 2011b, p. 16). After the 1992 elections, however, the NDC government was willing to take harsh measures to fix the fiscal imbalances that had resulted from their reckless politically motivated spending. Haynes (1995) observed that "after the elections, the government wanted to show to the World Bank that its capitulation to the civil servants was merely a tactic to help it gain electoral successes" (p. 113). Subsequently, the last PNDC budget announced on 5 January 1993, two days preceding the inauguration of the Fourth Republic, was nothing less than austere. A sixty percent increase in the price of petrol affected all sectors of the economy raising the prices of goods and services astronomically - in some cases by as much as 100 percent (Jeon 1998, p. 223; Haynes 1995). Operating within the constraints of IMF and World Bank conditionality, the NDC government was forced to cut down on public expenditure drastically after 1993. To make matters worse, inflation soured up precipitously and the cedi continued its sharp devaluation (Haynes 1995, p. 110). Indeed, by December 1995, inflation stood at 70.8 percent (Jeon 1998, p.223). Around this same period, the cedi had suffered about a 218 -fold reduction in its value vis-à-vis the U.S dollar since 1983 (Haynes 1995, 110). With such menacingly deteriorating economy and its impact on labor, workers' organizations were less likely to act with equanimity.

According to Haynes (1995), 'the first year of the Fourth Republic' was characterized with labor agitations and strikes because of the inflationary impact that followed the increased price of petrol and the inadequate wage levels of ordinary workers in Ghana' (p. 110). Indeed, one could say that workers were probably reacting to long-standing neglect and continuing impoverishment since the implementation of the structural adjustment policies in the 1980s. The PNDC government's ability to use repressive measures to counteract social unrest had ensured that workers had acquiesced to its austere economic measures and its impact on their wages and living conditions following the implementation of the adjustment policies in the 1980s (see Herbst 1993; Gyimah-Boadi \& EssumanJohnson 1993). Indeed, between 1986 and 1990, the minimum wage had lost about 20 per cent of its value; there was a further dip of 13 per cent between 1991 and 1993 (Haynes 1995, p. 111) and by the end of 1994, the monthly wages of public sector workers had decreased by 22 per cent - the highest in the first four years after transition (Hutchful 2002, pp. 90-91; Amoako 2014c, p. 19).

As the macro-economy continued to falter, so did workers conditions continue to deteriorate. By the time the NDC handed over power to the NPP in January 2001, Ghana's economic situation was dire, and workers were nothing less than impoverished. Macroeconomic indicators were faltering, and Ghana's treasury was burdened with huge debt, both foreign and local (Lindsay 2011b). 
John Agyekum Kufour of the New Patriotic Party, who assumed power in January 2001, in his maiden State of the Nation address painted a gloomy picture of the economy lamenting that it was characterised by mismanagement, huge unemployment, low wages increasing cost of living, huge national debt, high dependency on foreign aid, deteriorating health and educational facilities, unproductive private sector and massive corruption (Republic of Ghana, 2001. p. 2; Amoako-Gyampah, 2015, p. 66).

To solve the economic challenges, the NPP government, among other measures, reluctantly adopted the Highly Indebted Poor Country (HIPC) initiative in 2001. The reprieve gained enabled the government to stabilize the macroeconomy, create a business-friendly environment (see Bob-Milliar \& Bob-Milliar 2010; Killick 2010; Amoako-Gyampah 2015) and introduced some significant social intervention measures. Between 2002 and 2005, the government's fiscal discipline - 'tighter control over spending, with strict cash limits on spending ministries’ (Killick 2010, p. 415), helped to reduce Ghana’s budget deficit and the rate of monetary expansion. Killick (2010, p. 415) estimates that monetary growth was reduced from 50 percent in 2002 to 14 percent in 2005, and the inflation rate was brought down to a single digit in the early months of 2006 . Similarly, the ever-pervading depreciation of the cedi was for a while arrested. Other sectors of the economy put a strong showing compelling the World Bank to comment that Ghana was "in the middle of acceleration of economic growth" (quoted in Killick 2010, p. 415).

I should remark, however, that in spite of the strong prospects at economic growth, the NPP government hardly lived up to its economic goals. Lindsay (2011b) has observed that due to the NPP government's misplaced economic planning after 2004, by January 2009, the country had plunged into financial crises - budget deficit had soured up to 14.5 per cent of GDP, currency depreciation resurged, and inflationary tendencies bounced back - indeed, while inflation remained moderate until 2007, by 2008, it almost doubled to 20 per cent (Killick 2010, p. 417). Lindsay (2011b) further observed that while it is true that the NPP government had to deal with oil prices that steadily increased during its tenure, the gradual economic crises that peaked in 2009 did not cause the government to re-examine its economic policies nor to create new sources of foreign exchange to offset the emerging economic problems. The NPP government was, similarly, trapped in the election based spurt of spending. While the NPP government could avoid election-related spending in 2004 because it was sufficiently sure of victory, "the 2008 election demonstrated that an NPP government was willing to use its spending powers for electoral gain when it was less sure of voters' verdict" 
(Killick 2010, p. 415). The impact of such reckless politically-motivated spending on Ghana's economy was telling. ${ }^{7}$ Thus, when the NPP government left office in 2009 , the economy was little improved but equally as bankrupt as when they took over in 2001 (Lindsay 2011b, p. 25)

However, despite the economic difficulties, it would seem that the earlier respite gained from the HIPC initiative enabled the NPP government to commit to some appreciable level of social spending including increases in workers' salaries. Workers' salaries were improved substantially - indeed, in 2002, both the lowest and highest real wages of workers rose to 11.6 percent and 12.9 percent respectively. Similarly, in 2003 the lowest and highest real wages increased by 22.5 percent and 34.9 percent. In 2005 real wages increased by more than 28 percent (Bank of Ghana 2007, p. 8; Amoako-Gyampah 2015, p. 67). Notwithstanding these increases in salaries, however, the NPP government, just like its predecessor NDC administration, also had to contend with labor unrest, especially after 2004. Workers protested and embarked on sporadic strike actions to demand further improvements in salaries and improved conditions of work. Elsewhere I have argued that even the so-called macroeconomic gains that the NPP government was able to achieve appeared superficial and did not practically reflect in workers' living and working conditions (see Amoako-Gyampah, 2015).

The government's decision after 2004 to discontinue with the payment of subsidies on petroleum products and the subsequent pass-through of the changes in the cedi value of the international costs of petroleum and petroleum products to Ghanaian consumers coupled with astronomical increases in utility tariffs (Gocking 2005; Amoako 2015) seemed to have undermined the relief offered by the upward adjustments in workers 'salaries. As would be expected such developments were not received calmly by the working population - as the labor front saw several wild-cat strikes and stoppages (see Amoako-Gyampah 2015). Gocking (2005) has suggested that workers hardly benefitted from the so-called economic successes of the NPP administration acclaimed by the donor agencies. Consequently, after 2004 the government was under pressure to deal with the wanton budgetary excesses arising from the huge public sector wage bill. (Centre for Economic Policy Analysis, 2009; Amoako-Gyampah 2015). The government was thus unwilling to readily yield to workers' demands for increases in their salaries in the years after 2004 - the result of which was acute labor unrest (see Amoako-Gyampah 2015). The government was constrained in caving in to 
the workers' demands since any substantial wage increases could have aggravated the inflationary tendencies in the Ghanaian economy - tendencies that have pervaded Ghana's economic history since the 1960s, albeit with varying impacts.

It is my contention that while the opening of the democratic space with the inauguration of the Fourth Republic seemed to have enabled organized labor to operate freely, economic constraints and government's fiscal policies have thwarted their efforts at achieving substantial salary increases and improvements in the conditions of service of Ghanaian workers. For this reason, there has been an adversarial relationship between organized labor and government since 1992. Haynes (1995) observed that many, of Ghana's politically conscious unionized workers believed that the government wilfully denied workers substantial raises in the real value of the minimum wage. If this workers' sentiment was true for the NDC administration, the same could be said during the tenure of the NPP administration. We can surmise then that under Ghana's Fourth Republic economic considerations more than anything else seemed to have been critical to popular discontent and protest actions. Teachers' agitations and protest actions under the Fourth Republic have thus being influenced and conditioned by the broader political economy - they just like other public-sector workers have reacted to the ebbs and flow of governments' macroeconomic and fiscal policies which have negatively impacted on their working and living conditions. In the following sections, I discuss teachers' grievances and protest actions since $1993 .{ }^{8}$

\section{TEACHERS' GRIEVANCES UNDER THE NDC (1993-2000)}

Organised teachers were among the first group of workers to raise the red flag in the early years of the 1990s when the political environment was relaxed and accommodating of protest actions. ${ }^{9}$ The GNAT declared a nation-wide strike in March 1990. The strike lasted for two weeks and was in demand for improvement in basic salaries and allowances; establishment of a joint negotiation committee for regular determination of salaries and associated benefits; the establishment of the Ghana Education Service Council which the PNDC regime had abolished in

\footnotetext{
8 The following sections borrows liberally from previously published works by the author on this subject matter (see Amoako 2014b; Amoako-Gyampah 2015).

$9 \quad$ The PNDC government was less accommodating of protest actions during the 1980s. It used repressive measures to supress all forms of protest actions. However, the early years of the 1990s, when it became obvious that a democratic transition was inevitable, the regime relaxed its repressive measures as one of the measures to attract popular support - for it had reinvented itself and transformed the PNDC into NDC - an electoral machinery to contest the 1992 elections.
} 
1982; and the full implementation of all existing conditions of service (Ampaw 1995, p. 29; Amoako 2014c, p. 18). The government promised to resolve the grievances and prevailed on the teachers to return to work as it looked for a lasting solution (Amoako 2014c).

Following the failure of the PNDC regime and the successor NDC government to resolve the teachers' grievances, the GNAT once again declared a strike action on 31 May 1994 to put pressure on the government to address its long-standing grievances. Apart from the demand for payment of ex-gratia awards to retrenched 'pupil teachers' who had served in the Ghana Education Service for a period of five years (see Amoako, 2014c), all the other grievances which necessitated the 1994 strike action were concerned that teachers had raised since the 1980s which the PNDC regime had failed to address (Ampaw 1995, pp. 29-30). Apart from this strike action, GNAT again declared a dispute and called a six-day strike in 1999 which saw about 50, 000 teachers down their tools to demand salary increases and payment of arrears. In 2000, the NAGRAT also declared a strike action which involved 5000 teachers calling on the government to put graduate teachers on a separate entry level on the Ghana Education Service scale to reflect level 15 of the Ghana Universal Salary Structure (GUSS) (Amoako 2014c, p. 23). Implicitly, the graduate teachers were demanding for higher salaries since placement at that level on the GUSS meant an automatic increase in their salaries. The government resolved this strike and placed the graduate professional teachers on level 14 on the GUSS.

Two analytical points can be advanced to explain why strike actions became an important tool for organized teachers in the early years of the 1990s. Firstly, it could be said that it was the PNDC/NDC governments' intransigence and its often resort to bureaucratic delay tactics in settling the teachers' agitations that often compelled the GNAT to call its members to resort to strike actions (Amoako, 2014b). The events leading to the 1994 strike action, for example, are revealing. As early as April 1993, GNAT made arrangements to meet with the Minister of Education, Harry Sawyer to present to him its grievances. GNAT followed up this meeting with a memorandum on educational issues which were presented to the Minister on 17 May 1993 (GNAT 1993; Amoako, 2014c) This memorandum was followed with several other letters stating the grievances of teachers and requesting the government to address them (Amoako 2014c).

The government failed to respond either verbally or in writing to any of these letters and memorandum (Osei-Mensah 1994). In spite of this failure on the part of the government, the GNAT continued to look for non-confrontational means to get its grievances resolved. It sought for opportunities to hold meetings with the Minister for education to present to him to its concerns. For example, 
between 10 February and 31 May 1994, the GNAT held four different meetings with the Education Minister to discuss its grievances. Yet, none of these meetings yielded any positive outcome except that in one of such meetings, the Minister promised to present the GNAT's grievances to Cabinet for consideration (GNAT 1994). In another meeting convened on 25th April at the instance of the Minister, following GNAT's threat to embark on strike action, (Amoako 2014c, p. 21), the Minister promised to resolve all of GNAT's concerns. He subsequently gave definitive indications on how he was proceeding in resolving the grievances of the teachers (Amoako 2014, p. 21). Yet when on the 31st of May 1994, the GNAT met the Minister for briefing, it became clear to the GNAT leadership that the Minister had adopted a bureaucratic maze to frustrate their attempts at getting their grievances resolved - for the minister had done little or nothing concrete to assure GNAT of his commitment to resolving their grievances (Osei-Mensah 1994, p. 13). It was because of this that GNAT called its members to embark on strike action on 31 May 1994 (see Seini 1994, p. 9). It is thus clear that while the GNAT had remained extremely conciliatory in getting its grievances resolved, the government and its functionaries were rather tardy and appeared to be negotiating in bad faith. It would thus seem that if the government had been a little proactive in resolving the teachers' grievances these strike actions could have been avoided.

Secondly, it would appear that the teachers' grievances just like the grievances of other public-sector workers were driven by their ever-deteriorating economic conditions which pushed them to demand increased salaries and improved conditions of service to ease their impoverishment. Indeed, in spite of the modest attempts at transforming Ghana's economy since the 1980s, the liberalization policies adopted by the P/NDC government following the implementation of the economic recovery and adjustment programmes greatly disadvantaged the working population. The need to limit pay increases in keeping with the adjustment policies (see Nugent 1995, p. 169) had led to a situation where, by 1995, real wages of public sector workers had fallen to the extent that it was half of what it had been in $1970^{10}$ (see Overa 2007, p. 541). As Hansen (2003) has rightly observed, adjustment policies, in spite of its glorification by Western donors and their allied institutions, did thrust Ghanaian formal sector employees into the throes of economic hardship. The removal of subsidies on petroleum products and electrification tariffs even as the government remained constrained to cushion public sector workers with salary increases (as measures to stabilize the economy) impoverished the working population. 
It was the result of the difficult economic situation in which the average Ghanaian workers found themselves that between 1991 and 1995, the Consultative Forum of Labour which included GNAT, the Civil Servants Association (CCSA), Ghana Association of Registered Nurses (GRNA), and the Judicial Service Association (JUSAC) were engaged in a bitter struggle with government over higher salaries and better conditions of service. The reluctance of government to concede to demands for by the Forum and give to workers any appreciable income raises would result in sporadic strike actions which saw nurses down their tools in May/June 1992; and this was followed by other civil servants during the first two weeks of July the same year (Ampaw 1995, pp. 29-30). Following the announcement of the austere budget of the 1993 fiscal year, the Forum demanded an increase of 60 per cent in their income in order to recoup the loss in real income caused by the price hikes and the associated inflationary pressures - this, the regime was reluctant to accede to (Ampaw 1995, p. 29). The result was massive demonstrations and threats of strike actions throughout 1993 with spillovers in the following years. As Kumado and Gockel (2006) observed:

The inadequacy of incomes was compounded by intractable high rates of inflation and exchange rate depreciation so that those on fixed incomes particularly pensioners have become worse off. For example, although inflation was brought down from its highest ever level of $123 \%$ in 1983 to $10 \%$ by end of 1992 , it nevertheless remained intractable. Indeed, inflation, coupled with the steady decline of the cedi/dollar rate, which reverberates through the economy, has ever since been the bane of workers (p. 3).

Thus, we can surmise that the root cause of this government-labor impasse of which GNAT's agitation was part was over the question of wages and salaries - essentially, a fight to improve the material benefits of teachers. It thus appears from the foregoing analysis that the effects of Ghana's macroeconomic constraints in part fuelled the teachers' agitations and that government's tardiness in resolving these grievances then resulted in the often-sporadic strike actions which became a characteristic feature in the education labor arena during the period.

\section{THE NPP REGIME: NEW VISTAS FOR TEACHERS?}

After two successive terms of NDC rule under the leadership of Rawlings, the NDC new presidential candidate, Professor John Evans Atta-Mills lost the presidential race in a run-off in December 2000 to John Agyekum Kufour of the NPP. As I have mentioned earlier the NPP government inherited a stressed economy. Yet, perhaps owing to the ability of the new government to articulate 
clearly the economic position of the country and its proposed measures to turn the economy around, it received a lot of goodwill from Ghanaians generally and the working population in particular. Its efforts at the enactment and the promulgation of a new labor law; Labour Act 651 which had been in the pipeline since the 1990s was hailed by organized labor as a landmark in Ghana's labor history. Subsequently, the first term of the NPP government's administration witnessed fewer labor disputes. That is not to say, however, that there were no tensions at all on the labor front. Teachers in particular led by the GNAT threatened to embark on a strike action on 1 October 2001 to demand improved conditions of service and the implementation of supervision allowance. ${ }^{11}$ Similarly, the NAGRAT threatened to withdraw its services beginning from 28 April 2004 in demand for higher invigilation allowance. In both instances, the threats were withdrawn because according to the teachers the government's position on their grievances sounded reasonable and acceptable (Amoako 2012, p. 95; Amoako 2015).

This seemingly harmonious industrial relations in the education sector will last but only until the end of 2004 - for in 2005 and $2006^{12}$ the education sector witnessed some of the most prolonged labor disputes in Ghana's labor history. Interestingly, NAGRAT was at the forefront of these agitations. That is not to say that the issues over which NAGRAT declared strike actions concerned only graduate teachers - the issues affected non-graduate teachers as well - and in fact in 2006, rank-and-file members of GNAT members declared sporadic wild-cat strikes in solidarity with NAGRAT even though the leadership of GNAT distanced itself from the strike action (see Amoako-Gyampah 2015). ${ }^{13}$ On 6 May 2005 NAGRAT declared a strike action in protest against government's lackadaisical attitude in resolving their grievances which included: failure of the Ghana Education Service (GES) to address teachers' demands for increased responsibility allowance; the reluctance of the Ministry of Education and the

11 Supervision and invigilation allowances are paid to teachers who take up additional responsibilities as invigilators and supervisors for external examinations of the Ghana Education Service. The Ghana Education Service depend on the West African Examination Council (WAEC) to organise the Basic School Certificate Examination which qualifies basic students to enter Senior High Schools. At the senior high school level, a similar examination, which is the West African Senior School Certificate Examination which is the qualifying examination for entry into tertiary institutions is also conducted by the same organisation.

13 It would seem that after several years of operating on the side-lines of the education labour terrain since its registration and inauguration in 2008, the NAGRAT was at this point asserting its presence in the education labour arena. Of course, the formation of NAGRAT was goaded by the perceptions that GNAT was reluctant to pursue the interest of its graduate membership cohort. Besides, it appeared less likely that with two women occupying the most important leadership positions in the GNAT, one could expect any intense agitation from the GNAT. In 2002, Irene Duncan Adanusa, the first ever female general secretary of the GNAT, replace Paul Osei Mensah who had served since 1983. The presidential position also fell to Portia Molly Anafo. With their motherly instincts and concern for children one could only expect a cautious agitation from GNAT's front. 
GES to approve and fix dates for promotion of assistant directors and grades above those; the GES's delay in issuing letters to teachers who had been promoted to the grades of Superintendents and Principal Superintendents; the failure of the GES and the West African Examinations Council (WAEC) to pay full supervision allowances due to teachers (Gobah 2005, p. 3; Amoako 2015, p.11).

Agitations for most of these demands had begun since January 2004. NAGRAT wrote several letters, presented several memoranda and held several meetings with the Ministry of Education - all in attempt to get these grievances resolved; in some instances, there were threats and counter threats from both the Ministry of Education and GES on the one hand and NAGRAT on the other. Yet no tacit conclusions were reached - and the resulting frustration prodded NAGRAT to resort to strike action as the last option (Amoako 2015, pp 11-13). About a month into the strike action, the Education Sub-committee of Ghana's Parliament offered to broker peace between NAGRAT and the government. The Committee succeeded in persuading NAGRAT to return to work as it continued with negotiations to find a lasting solution to the dispute. It appeared that once the teachers resumed work, little was done to resolve their grievances (see Amoako 2015). The failure of the GES and the Ministry of Education to find a lasting solution to the concerns of the teachers thus underpinned the resort again to strike action by NAGRAT in 2006.

The 2006 NAGRAT strike begun on 1 September 2006 and continued for almost eight weeks. Apart from the demand for the government to implement all outstanding grievances on which Memorandum of Understanding had been reached (these included, invigilation allowances, payment of responsibility allowances ${ }^{14}$, issuance of letters of conversion to all graduate teachers, irrespective of whether they were professionals or not); NAGRAT also demanded to be represented on all GES committees and panels and also on the GES Council - which is the governing body of the education sector and demanded the reimbursement of teachers whose salaries had not been paid since 2003 (AmoakoGyampah 2015). Most of these demands were unresolved grievances from the 2005 strike that had been restated. The central concern during the 2006 strike, however, was the demand for an upward adjustment in salaries. Just like events leading to the 2005 strike action, NAGRAT had exhausted both the formal and informal channels to get its grievances resolved before it finally decided to embark on strike action. Following a threat in March 2006 to embark on a strike action if its grievances from 2005 were not resolved, the Minister of Education, Yaw Osafo Marfo, intervened and persuaded the teachers to withdraw their threat, promising

14 Responsibility allowance is paid to teachers who take up additional responsibilities as head teachers/ head masters, house masters/mistresses (in boarding schools), head of departments, etc. 
to ensure that the teachers' grievances would be resolved (NAGRAT 2006; Amoako-Gyampah 2015). Interestingly the Minister was removed from office before he could see to the execution of his promise and neither his successor nor the GES and the Ministry of Education took any concrete measures to address the concerns of the teachers. It was this failure on the part of the education authorities that incited NAGRAT to call the strike action.

It is obvious from the above narration that in both the 2005 and 2006 strike actions, it was the government's laxity in finding lasting solutions to the teachers' grievances that prodded NAGRAT to embark on strike actions. In both instances, the teachers used several negotiation channels to seek redress and resorted to strike actions only as a last resort (see Amoako-Gyampah 2015). Their grievances concerned fundamentally demands improvements in their conditions of service and agitations for salary increases. I must, however, remark that concerning salaries, the NPP government increased the salaries of teachers substantially. For example, in 2003 the average basic monthly salary of the non-professional graduate teacher was $\phi 1,422,836$ (equivalent to $\$ 160.7) .{ }^{15}$ The professional graduate teacher during the same period earned an average basic monthly salary of $\notin 1,641,465$ (equivalent to $\$ 185.4$ ). By 2006 , the average basic monthly salary of the non-professional graduate teacher had increased to $\varnothing 2,400.105$ (equivalent to $\$ 270.4$ ) and that of the graduate professional to $₫ 2,877,726$ (equivalent to $\$ 313.5$ ) (Amoako-Gyampah 2015, p. 68). Thus, in a space of three years, the salaries of both professional graduate teachers and non-professional graduate teachers had almost doubled.

Yet, the demand for salary raises and improvement in related conditions of service became cardinal to teacher agitations in both 2005 and 2006. As I have stated earlier, the deregulation of the oil market and the subsequent burden on Ghanaian consumers to pay realistic market prices for petroleum products as well as well as an upward adjustment in utility tariffs, and other cost-saving measures adopted by the NPP government to stabilise the macro-economy appeared to have undermined the salary raises which the government offered to Ghanaian workers. Besides the government was under pressure to find ways to minimize the public-sector wage bill which had become the bane of government expenditure, and a major contributing factor to budgetary excesses. It was for this latter reason

15 A maximum of 8 hours a day or 40 hours a week is set for all public sector workers including teachers. However, teachers in basic schools maintain 7 hours contact a day with pupils. There is a common contract for all public school teachers in Ghana and variations are dependent on levels of qualification and the duration of service. That is the say that teachers are promoted and ranked based on both levels of qualification and long service. Pay levels are thus commensurate with ranks. For example, newly recruited diploma teachers start as Senior Superintendent II, Bachelor degree holders are recruited as Senior Superintendents, and subsequent promotion to the ranks of Assistant Director, Deputy Director and Director are contingent on long service and after having passed a promotion interview. 
that the government adopted a tactical decision to delay salary negotiation and wage settlements during the 2005 fiscal year (see Centre for Economic Policy Analysis 2009) - a move which saved the country an amount equivalent to $0.4 \%$ of GDP. Interestingly, this decision would partly contribute to the labor unrest which was witnessed in 2005 and 2006 respectively (see Amoako-Gyampah 2015). Indeed, one observer declared 2006 as the season of strikes because of the number of labor disputes that were recorded - all over wages and improvements in conditions of service (Coleman 2006; Amoako-Gyampah 2015).

\section{CONCLUSION}

Teachers' protest actions under Ghana's Fourth Republic have manifested itself in the form of strike actions to demand salary increases and improvements in teachers working conditions. However, the teachers' organizations have resorted to strike actions only as a last resort to get their grievances resolved. Often, the teachers' unions have sought to resolve their grievances through the available negotiation channels. However, the various governments, that have ruled since the inauguration of the Fourth Republic, first the NDC and later the NPP have both in diverse ways frustrated the teachers' unions' efforts and have remained tardy - negotiating in bad faith - in resolving the teachers' grievances. It thus appears that it is the governments' indifferent attitude towards resolving teachers' grievances that have often pushed the teachers' unions to declare strike actions. These strike actions have however been fuelled by the ebbs and flows of Ghana's faltering political economy and government's macroeconomic measures and its negative impact on the living and working conditions of the teaching profession. It would seem also that government's laxity in responding to, and addressing the teachers' grievances timely, has been shaped and conditioned partly by their commitment to implementing their economic measures, most of which have been unpopular amongst the working population. Economic constraints have thus defined teachers' agitations as well as conditioned government responses.

\section{REFERÊNCIAS}

Adu-Amankwa, K. \& Tutu, K. (1997). 'Ghana: Going beyond Politics.' In Trade Unions and Sustainable Democracy in Africa, Kester, Gerard \& Sidibe, Oumarou Ousamne (Ed). 207-228. England \& USA: Ashgate Publishing Company. 
Amoako, S. (2012). 'Teachers' Unions and Politics in Ghana and South Africa, 1990-2010. 'Unpublished Master's Dissertation, University of Johannesburg, South Africa.

Amoako, S. (2014a). 'Teaching and Labour: Teacher Unionism in Ghana, 19311966.' International Journal of African Historical Studies, vol. 47 no 1, pp $55-75$.

Amoako, S. (2014b). 'The Ghana National Association of Teachers Under the Provisional National Defence Council, 1982-1991: Caught in a Warp of Cooperation and Unresolved Grievances.' Contemporary Journal of African Studies, vol. 2 no. 1, pp. 1-25.

Amoako, S. (2014c). 'Black Board Struggles: Teacher Unionism under the 'Democratic' Rawlings Regime, 1992-2000.' Ghana Studies, Vol. 17. pp. 7-38.

Amoako-Gyampah, A. K. (2015). "Striking Where It Hurts: The Political Economy of Graduate Teachers Strikes and Labour Relations in Ghana's Public Education Sector African Review of Economics and Finance, Vol. 7, no. 2. pp. 60-83

Ampaw, A. (1995). 'The state of the Nation: Rumblings on the Labour Front.' In Ghana: The Kumepreko Demonstrations, Poverty, Corruption and the Rawlings Dictatorship, Napoleon Abdulai (Ed.). pp 21-33. London: Africa Research and Information Bureau.

Aryeetey, E. \& Kanbur, R. (2008). 'Ghana's Economy at Half-century: An Overview of Stability, Growth and Poverty.' In The Economy of Ghana: Analytical Perspectives on Stability, Growth and Poverty, Ernest Aryeetey \& Ravi Kanbur (Ed). Pp. 1-19. Oxford: James Curry Ltd.

Asiedu-Akrofi, K. (1971). Teachers' Association in Ghana: An Analytical Study. Cape Coast: University Press.

Ato-Coleman, H. 2006. “A Season of Strikes in Ghana: A Rapid Analysis.” Daily Graphic, 21 June. 
Bob-Milliar, G, and Bob-Milliar K. G. (2010). 'The Economy and Intra-Party Competition: Presidential Primaries in the New Patriotic Party of Ghana.' African Review of Economics and Finance vol. 1, no 2 pp. 51-71.

Compton, M. \& Weiner, L. (2008). The Global Assault on Teaching, Teachers and their Unions: Stories of Resistance. New York: Palgrave Macmillan.

Darkwah, K. (2014). A History of GNAT. Accra: Woeli Publishers

GNAT (1993). 'Memorandum on Educational Issues submitted to the Ministry of Education.' Accra: GNAT Archives.

Gocking, S. R. 2005. The History of Ghana. Greenwood Press.

Hansen, T. K. (2003). 'Creative Allocation of Space as a response to Economic Crises.' In Critical Perspectives in Politics and Socio-economic Development in Ghana, Wisdom Tettey J, Puplampu, Korbla, \& Bruce, J. Berman (Ed). Pp. 93-115. Leiden \& Boston: Brill.

Haynes, J. (1995). 'Ghana: From Personalist to Democratic Rule.' In Democracy and Political Change in Sub-Saharan Africa, John A. Wiseman (Ed). Pp. 9315. London \& New York: Routledge.

Herbst, J. (1991). "Labour in Ghana under Structural Adjustment: The Politics of Acquiescence" in Ghana: The Political Economy of Recovery, Rothchild, Donald (Ed). Boulder and London: Lynne Rienner Publishers

Hutchful, E. (2002). Ghana's Adjustment Experience: The Paradox of Reform. Geneva: UNRISD.

Jefferies, R. (1978). Class, Power and Ideology in Ghana: The Railwaymen in Sekondi. Cambridge: Cambridge University Press.

Jefferies, R. (1982). "Rawlings and the Political Economy of Underdevelopment in Ghana.” African Affairs, Vol. 81, no. 324. Pp. 307-317

Jeon, H. (1996). 'Ghana: Lurching Toward Economic Rationality.' World Affairs, vol. 159, no. 2. Pp. 64-71 
Jeon, H. (1998). 'Economic Reform and Democratic Transition in Ghana.' World Affairs, vol. 160, no. 4. Pp. 218-230.

Killick, T. (2010). Development Economics in Action: A Study of Economic Policies in Ghana (2nd edition). USA \& Canada: Routledge.

Kraus, J. (2007). 'Trade Unions, Democratization, and Economic Crises in Ghana.' In Trade Unions and the Coming of Democracy in Africa, Jon Kraus (Ed). Pp. 83-121. New York: Palgrave Macmillan.

Kraus, J. (1979). 'Strikes and Labour Power in Ghana'. Development and Change, Vol. 10. pp. 259-86

Kumado, K. \& Gockel, A. F. (2006). 'A study on Social Security in Ghana.' Unpublished Manuscript.

NAGRAT, (2006). "Intended Industrial Action on Hold". Press Release, Ref No. NGT/NS/P-S/009/06. NAGRAT Archives, Accra.

Nugent, P. (1995). Big Men, Small Boys and Politics in Ghana: Power, Ideology and the Burden of History. Ghana: Asempa Publishers.

Osei, M. G. (2006). 'Teachers in Ghana: Issues of Training, Remuneration and Effectiveness.' International Journal of Educational Development, vol. 26. No 1. Pp 38-51

Osei-Mensah, P. (1994). 'The Teachers' Cause.' Daily Graphic July 20. Pp. 3 \&13.

Overa, R. (2007). 'When Men do Women's Work: Structural Adjustment, Unemployment and Changing Gender Relations in the Formal Economy of Accra, Ghana.' Journal of Modern African Studies, vol.45, no. 4. Pp. 539-563.

Republic of Ghana (2001). State of the Nation Address. Accra: Assembly Press.

Robertson, S (2000). A Class Act: Changing Teachers Work, the State and Globalisation. New York: Falmer Presss 
Sang, A. K. (2002). 'Interest Groups in Education: Teachers' Perceptions of the Effectiveness of the Kenya National Union of 'Teachers.' Unpublished PhD Dissertation, University of Cape Town.

Seini, I. (1994). ‘Teachers to go on strike on May 31.’ Daily Graphic, May 27.

Whitfield, L. (2011a). 'Competitive Clientelism, Easy Financing and Weak Capitalists: The Contemporary Political Settlement in Ghana.' Danish Institute for International Studies Working paper, no. 27

Whitfield, L. (2011b). 'Growth without Economic Transformation: Economic Impacts of Ghana's Political Settlement.' Danish Institute for International Studies Working paper, no. 28.

AKWASI KWARTENG AMOAKO-GYAMPAH [previously known and called Samuel Amoako] is a doctoral candidate in the Department of Historical Studies, University of Johannesburg, South Africa. Before he registered for his $\mathrm{PhD}$, he lectured in the Department of History Education, University of Education, Winneba, Ghana, from where he took study leave in 2016. His publications have appeared in the International Journal of African Historical Studies (2014), Ghana Studies (2014), Journal of Asian and African Studies (2014), Contemporary Journal of African Studies (2014), and African Review of Economics and Finance (2015). His interests in African studies spans political economy, comparative labour history, economic history, and social history of medicine and public health. His current research focuses on sanitation and public hygiene in colonial and post-colonial Ghana. E-mail: akwasikwarteng amoakogyampah@yahoo.com 